ORIGINAL RESEARCH PAPER

\title{
MULTIPLEXED Stn AND PlcA BASED SPECIFIC GENETIC MARKER FOR EARLY DETECTION OF Salmonella enterica AND Listeria monocytogenes IN MILK SAMPLES
}

\author{
KRITIKA SAINI ${ }^{1}$, ANKUR KAUSHAL ${ }^{2}$, SHAGUN GUPTA ${ }^{1}$, DINESH KUMAR ${ }^{1 *}$ \\ ${ }^{1}$ Shoolini University of Biotechnology and Management Sciences, Bajhol, PO Sultanpur, Distt. Solan- 173229 \\ (HP), India. \\ ${ }^{2}$ Amity University, Manesar, Gurugram -122413, Haryana, India \\ *corresponding author: dkchatanta@gmail.com
}

Received on $25^{\text {th }}$ June 2019

Revised on $17^{\text {th }}$ September 2019

\begin{abstract}
In this study conventional PCR and multiplex PCR based method was developed for the detection of two common foodborne pathogens Salmonella enterica and Listeria monocytogenes in 20 raw milk samples. The PCR was undertaken to detect two genes namely, Salmonella enterotoxin (stn) gene and phosphatidylinositol-specific phospholipase $\mathrm{C}$ gene $(p l c A)$ from both the organisms. The DNA templates (for both organisms) were amplified using specific set of primers. The resulting amplicons were found to be $265 \mathrm{bp}$ and $147 \mathrm{bp}$ respectively. Validation studies were further performed in artificial spiked milk samples and raw milk samples using multiplex PCR. The available detection methods are bacterial culturing, biochemical tests, serological tests, antibiotic sensitivity, ELISA and PCR. All these methods are either expensive or non-confirmatory and have some limitations. The reported multiplexed PCR based genetic marker completes overall analysis in $80 \mathrm{~min}$ which is the minimum time reported so far for the confirmation of these foodborne pathogens. Sensitivity and specificity of developed method was calculated and compared with different conventional methods. The detection limit of the assay for the S. enterica was $6.6 \times 10^{\circ} \mathrm{CFU} / \mathrm{mL}$ and for L. monocytogenes was $4.5 \times 10^{0} \mathrm{CFU} / \mathrm{mL}$.
\end{abstract}

Keywords: Salmonella enterica, Listeria monocytogenes, raw milk, conventional PCR, multiplex PCR

\section{Introduction}

Food safety is a global health issue. At present the concern for food safety and quality has gained massive importance in the food industry as the chance for contamination of food has increased by the spread of food borne pathogens. Any pathogenic microorganism in food can lead to severe health related problems in

https://doi.org/10.35219/foodtechnology.2019.2.01 
both humans and animals (Arora et al., 2011). As identified by the Center for Disease Control and Prevention (CDC), approximately 48 million of Americans get sick, 128,000 are hospitalized and 3,000 die each year from food poisoning (Oliver et al., 2005; CDC, 2014). From last 29 years (1980-2009) a total of 37 foodborne outbreaks have been registered of which 3,485 persons have been affected due to food poisoning in India (Rao et al., 2012).The food poisoning outbreaks in India were increased up to $85 \%$ from last 9 years. A total of 1,649 disease outbreaks have been registered from the year (2008-2017), 312 cases were of acute diarrhoeal disease and 242 cases were of food poisoning (NCDC, 2017).

Raw meat, vegetables, milk, eggs, seeds might be a source of contamination with bacteria, such as L. monocytogenes and S. enterica that may be transmitted through cross-contamination events during food preparation. Salmonella spp. is a foodborne pathogen that is typically acquired through consumption of contaminated food and water and causes severe clinical manifestations, including acute gastroenteritis and typhoid fever (Boyle et al., 2007). It has been proposed that Salmonella enterotoxin (Stn) is a putative virulence factor and causative agent of diarrhea (Chopra et al., 1999) and stn gene is specifically distributed in Salmonella spp. irrespective of their serotypes (Dinjus et al., 1997; Makino et al., 1999; Moore \& Fiest, 2007; Lee et al., 2009). On the other hand, L. monocytogenes is one of the foodborne pathogen responsible for listeriosis, a rare but fatal disease with mortality rate in pregnant women (Bhunia, 2018). This bacterium enters into cell by inducing its own phagocytosis. The bacterium contains the virulent factors which disrupts the vacuolar membrane and causes listeriosis in both animals as well in humans. PlcA gene of L. monocytogenes is a virulent gene and encodes $33 \mathrm{kDa}$ protein responsible for lysis of the primary single-membraned vacuoles (Vazquez et al., 2001). In addition, it can cause encephalitis, septicaemia and meningitis while in pregnant women, may lead to still birth or premature birth of the fetus (McLauchlin et al., 2004). There are various conventional screening methods available for the detection of pathogens that includes plating combined with immunological or biochemical identification and serological methods. Most of methods are time consuming, laborious, and less specific (Abubakar et al., 2007; Kim et al., 2006; Jarvik et al., 2010). To overcome these limitations, various molecular and genetic-based approaches such as polymerase chain reaction (PCR) (Park et al., 2009; de Freitas et al., 2010; Liu et al.,2012; He et al., 2016), sequence-based serotyping, and DNA microarray hybridization (Guard et al.,2012; Li, 2016) methods have been developed. Recently, specific PCR based-markers have gained importance in pathogen detection due to fast detection and high accuracy in comparison to the conventional methods (Kim et al., 2006).

The aim of present study was to develop a specific genetic marker for the detection of $S$. enterica and L. monocytogenes in different raw milk samples using conventional PCR and multiplex PCR (mPCR) techniques with more sensitivity and specificity. 
Materials and methods

\section{Sample collection and chemicals}

The bacterial strains of Listeria monocytogenes (MTCC 657), Salmonella enterica (MTCC 9844), Klebsiella pneumoniae (MTCC 39), and Enterobacter aerogenes (MTCC 2824) used in present study were obtained from MTCC, Institute of Microbial Technology, Chandigarh, India. PCR chemicals and Taq polymerase were obtained from Bangalore GeNei, India. Tris, EDTA and DNA purification kit (Hipura ${ }^{\mathrm{TM}}$ Purification kit) was purchased from Hi-media. Primers were synthesized from Eurofins Genomics India Private Limited, India.

\section{Genomic DNA isolation from bacterial culture}

The genomic DNA was also isolated from 24h cultured S. enterica (MTCC 9844 IMTECH Chandigarh) and L. monocytogenes (MTCC 657 IMTECH Chandigarh) in brain heart infusion broth using phenol chloroform method (Kaushal et al., 2012). For quantification and purity $\left(\mathrm{A}_{260 / 280}\right)$ determination, the genomic DNA sample was measured by Nanodrop spectrophotometer.

\section{Genomic DNA isolation from artificial spiked milk samples}

Twenty raw cow milk samples were collected from different places of district Solan, (Himachal Pradesh) India and five milk samples were artificially spiked with $7.5 \times 10^{0} \mathrm{CFU} / \mathrm{mL}^{-1} S$. enterica and $8.5 \times 10^{0} \mathrm{CFU} / \mathrm{mL}^{-1}$ L. monocytogenes strains in BHI broth and incubated at $37^{\circ} \mathrm{C}$ overnight. From each sample, $1 \mathrm{~mL}$ of spiked milk sample was centrifuged at $12000 \mathrm{rpm}$ for $10 \mathrm{~min}$. The pellet obtained was dissolved in $100 \mu \mathrm{L}$ of TE buffer and heated at $95^{\circ} \mathrm{C}$ for $5 \mathrm{~min}$. After heating, all tubes were centrifuged at $8000 \mathrm{xg}$ for $3 \mathrm{~min}$, afterwards the pellet was washed with sterile water (centrifugation) and finally dissolved in $10 \mu \mathrm{L}$ of TE buffer. One $\mu \mathrm{L}$ of bacterial DNA was further used in the assays.

\section{Primer designing and amplification of target gene by using PCR}

The primers used in this study are listed in Table 1. The sequence of stn gene of $S$. enterica and plcA gene of L. monocytogenes were retrieved from NCBI and checked for the homology with other organisms. The presence of stn and plcA genes was assessed in all spiked milk samples by PCR with the following steps: initial heating at $95^{\circ} \mathrm{C}$ for $2 \mathrm{~min}$, followed by 22 cycles of denaturation at $95^{\circ} \mathrm{C}$ for $30 \mathrm{~s}$, annealing at $57^{\circ} \mathrm{C}$ for $30 \mathrm{~s}$, extension at $72^{\circ} \mathrm{C}$ for $30 \mathrm{~s}$ and final extension for 5 min. Genomic DNA of K. pneumoniae was taken as negative control. The PCR reaction mixture contained $10 \mathrm{X}$ assay buffer, $10 \mathrm{mM}$ of dNTP $(2.5 \mathrm{mM}$ of each $\mathrm{dATP}$, dGTP, dCTP and dTTP), $10 \mu \mathrm{M}$ each of forward and reverse primers, genomic DNA (100 ng), 0.50 units Taq polymerase and Milli Q water up to a final volume of $25 \mu \mathrm{L}$. Sharp band was visualized in UV light at different base pairs in comparison with the DNA marker. The amplified PCR products were purified using a commercial kit and the agarose gel electrophoresis of the PCR products was carried out in $1.5 \%$ agarose gel at $90 \mathrm{~V}$. The purified PCR product was sequenced by Xceleris Labs Limited and Eurofins Genomics India Private Limited, India and homology of both the genes was confirmed by BLAST. 


\section{Multiplex PCR}

mPCR was standardized for detecting artificially spiked milk samples with $S$. enterica and $L$. monocytogenes for detecting specific virulent genes in a single PCR vial containing both the primer sets for these genes. The DNA template preparation from milk samples containing both organisms was done as per the methods employed for the isolation described earlier. The standardized PCR protocol as described earlier for $25 \mu \mathrm{L}$ reaction mixture was performed. Agarose gel electrophoresis of amplified PCR product was carried out in 1.5\% agarose gel at 90 V. Sharp band with $265 \mathrm{bp}$ was visualized in UV light for stn gene and $147 \mathrm{bp}$ for plcA gene.

Table 1. Primers used in PCR assay with their sequence, target gene and expected amplified DNA fragment

\begin{tabular}{lcccc}
\hline Microorganism & Sequence & $\begin{array}{c}\text { Target } \\
\text { gene }\end{array}$ & $\begin{array}{c}\text { Expected PCR } \\
\text { product size }\end{array}$ & Reference \\
\hline $\begin{array}{l}\text { Salmonella } \\
\text { enterica }\end{array}$ & $\begin{array}{c}\text { Forward Primers- } \\
\text { CGGTCGTCCCACTTCTT } \\
\text { Reverse Primers - }\end{array}$ & Stn & $265 \mathrm{bp}$ & $\begin{array}{c}\text { Present } \\
\text { study }\end{array}$ \\
\hline $\begin{array}{l}\text { Listeria } \\
\text { monocytogenes }\end{array}$ & $\begin{array}{c}\text { Forward primer - } \\
\text { TTACTTGTTAGGTGCGCCG } \\
\text { Reverse primer- }\end{array}$ & plcA & $147 \mathrm{bp}$ & $\begin{array}{c}\text { Present } \\
\text { study }\end{array}$ \\
\hline
\end{tabular}

\section{Specificity of PCR}

The specificity of the standardized PCR was analyzed by screening the standard strains of $S$. enterica and $L$. monocytogenes with other commonly known prevalent and cross-reacting bacterial pathogens ( $K$. pneumoniae and $E$. aerogenes). The DNA template preparation from the test organisms and other PCR conditions were identical to those as described earlier.

\section{Sensitivity of the PCR}

To determine sensitivity by using mPCR, $2 \mathrm{~h}$ incubated milk samples containing both the foodborne pathogens $S$. enterica and L. monocytogenes were serially diluted and cell lysates were used as templates for the PCR amplification. Each sample containing pathogen was diluted to $10^{9}, 10^{8}, 10^{7}, 10^{6}, 10^{5}, 10^{4}, 10^{3}, 10^{2}$, and $10^{1}$ bacterial cell $/ \mathrm{mL}$.

\section{Validation studies with raw milk samples}

Validation studies of 20 raw milk samples and 2 positive controls (artificially contaminated with $S$. enterica and L. monocytogenes were performed with conventional methods (Gram staining and different biochemical tests (catalase, Oxidase, Methyl Red and Voges Proskauer test) were performed (USFDA/CFSAN, 2003) as well mPCR.

\section{Results and discussion}

In the present study PCR protocol was optimized for the standard strains that could detect individual virulent genes for S. enterica (stn) and for L. monocytogenes 
(plcA). Sequence of 265 bp amplicon after BLAST showed $94 \%$ similarity with sth gene of $S$. enterica and $147 \mathrm{bp}$ amplicon after BLAST showed $94 \%$ similarity with plcA gene of L. monocytogenes that confirmed the amplification of right fragment. Primers used in this experiment were specific and amplifies only the specific region under specific conditions (Figure 1).

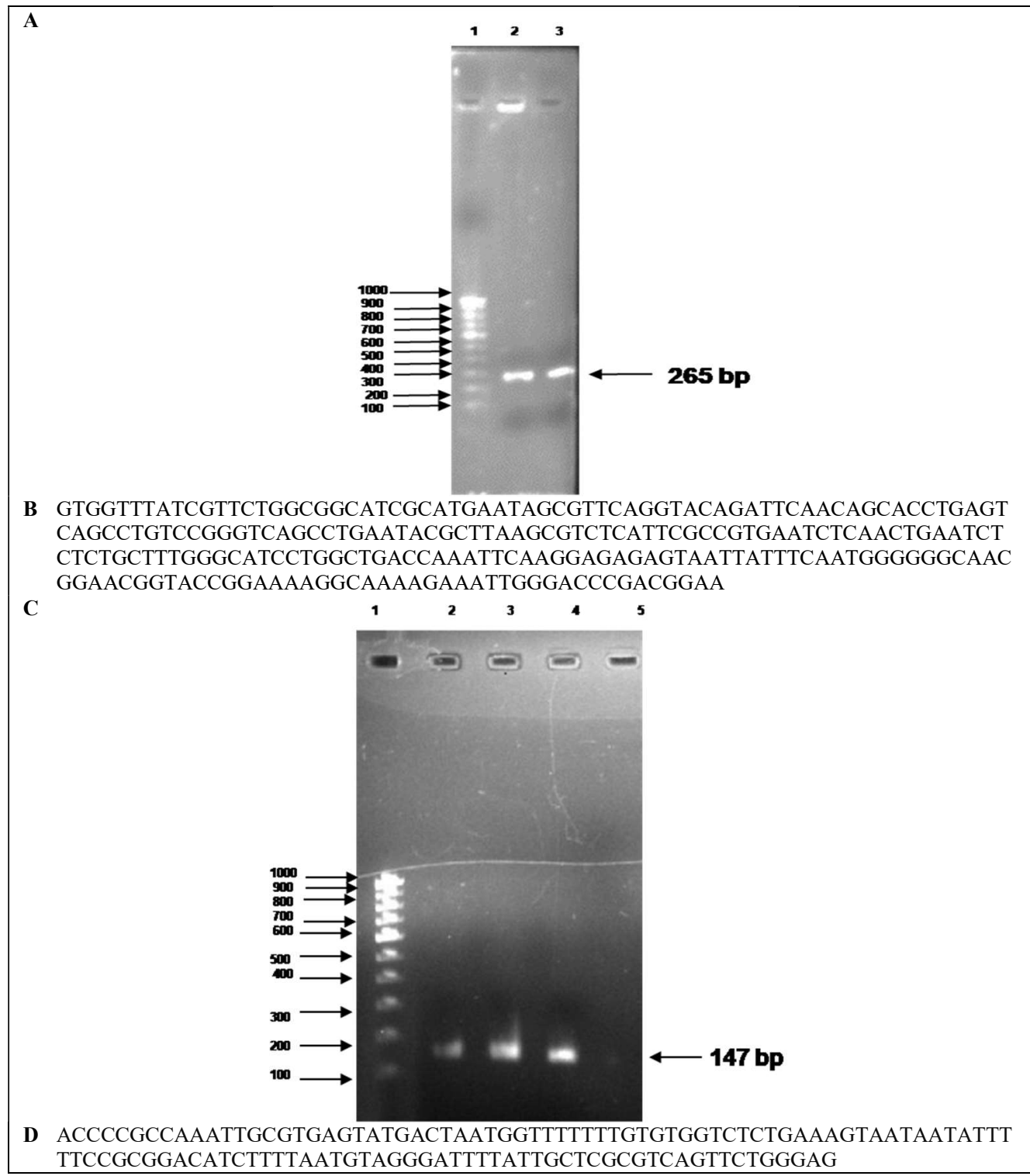

Figure 1. [A and C] Agarose gel electrophoresis (1.5\%) of PCR product of sth gene of $S$. enterica and plcA gene of L. monocytogenes Lane1: DNA marker 100bp; In [A] Lane 2, 3 PCR product stn gene of $S$. enterica (265 bp). [B] Gene sequence of PCR product (265 bp); In [C] Lane: 2, 3, 4 - PCR product of plcA gene of L. monocytogenes (147 bp). [D] Gene sequence of PCR product (147 bp) 


\section{Multiplex PCR artificially Spiked milk samples and validation studies}

The mPCR was developed for the detection of pathogens in artificially spiked raw milk samples (Figure 2). Various methods for the detection of $S$. enterica and $L$. monocytogenes in raw milk samples are available like culturing, biochemical tests, antibiotic sensitivity, ELISA etc. but all these methods are time consuming, labor intensive and less sensitive (Law et al., 2015). The results suggest that stn gene and plcA gene can be used as specific genetic markers for the detection of $S$. enterica and L. monocytogenes, respectively. Amplicons of $265 \mathrm{bp}$ of stn gene and $147 \mathrm{bp}$ of plcA genes do not show homology on BLAST with other organisms and therefore can be used as a genetic marker for early detection of $S$. enterica and $L$. monocytogenes involved in food poisoning episodes.

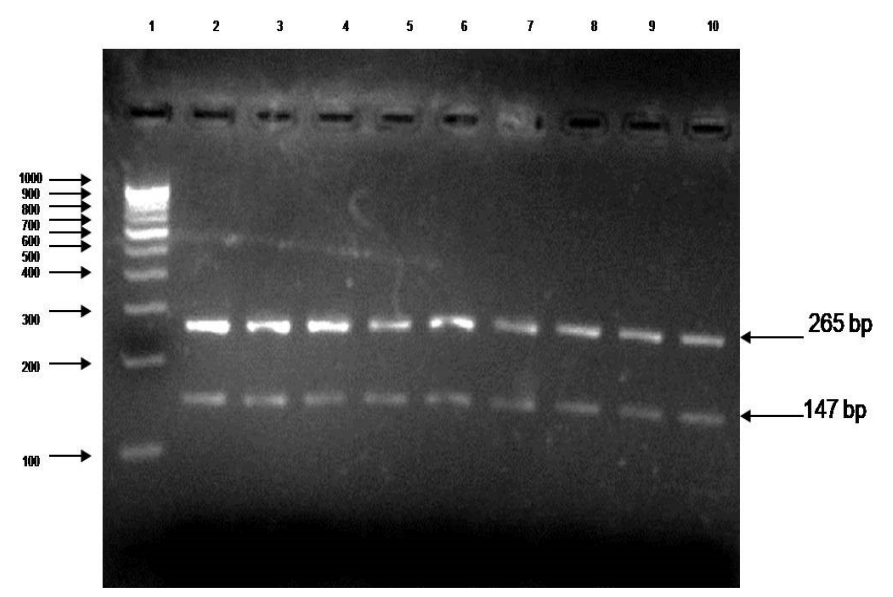

Figure 2. Agarose gel electrophoresis (1.5\%) of PCR product of stn gene of S. enterica and plcA gene of L. monocytogenes. Lane1: DNA marker 100bp; Lane: 2-5 - genomic DNA of

S. enterica and L. monocytogenes (positive control): Lane: 6-10 containing artificially spiked raw milk samples for detection of $S$. enterica and L. monocytogenes, respectively

The detection of $S$. enterica and L. monocytogenes in 20 different raw milk samples was carried out with conventional methods (Table 2) as well as with mPCR (Figure 3). In Figure 3 last lane, corresponding to NC, do not show any amplified band (in which genomic DNA of $K$. pneumoniae was used). Samples 1 and 2 were used as control (positive test) using artificially spiked raw milk samples with $S$. enterica and L. monocytogenes. Samples 8 and 12 showed positive results with PCR method and their amplified bands corresponded to $265 \mathrm{bp}$ stn gene of $S$. enterica and samples 7,13 and 15 showed positive results with PCR method and their amplified bands corresponded to $147 \mathrm{bp}$ plcA gene of L. monocytogenes. Samples 13 and 14 were catalase positive whereas the others were negative, which suggests that catalase test is not specific for $S$. enterica. On the other hand, sample (6 and 17) were catalase positive whereas other samples were negative suggesting that catalase test is not specific for $L$. monocytogenes. Other conventional test showed some limitations such as Gram staining for S. enterica in which samples 8 and 12 failed to be detected but positively detected with the PCR based detection 
method. The same situation has been registered for L. monocytogenes in which samples 7, 13, and 15 could not be identified by Gram staining but were positive with the PCR detection method. Therefore, the PCR based method using stn and plcA gene based specific primers resulted in successful amplification of $265 \mathrm{bp}$ and $147 \mathrm{bp}$ amplicons. Hence, stn gene and $p l c A$ genes can be used as markers for early detection of $S$. enterica and L. monocytogenes to prevent foodborne illnesses. The present method is simple, economical and fast as it takes only $80 \mathrm{~min}$ for the detection of foodborne pathogens.

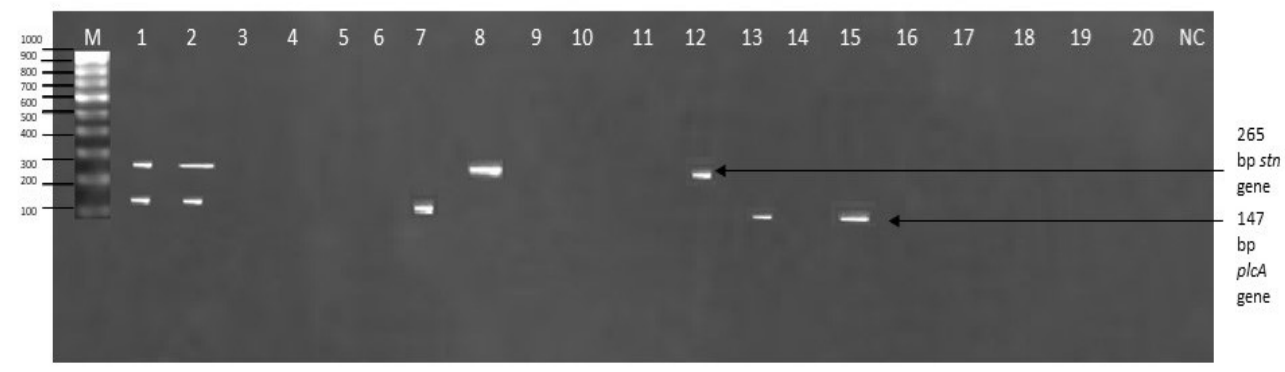

Figure 3. Agarose gel electrophoresis (1.5\%) of PCR product of sth gene of S. enterica and plcA gene of L. monocytogenes. Lane M: DNA marker $100 \mathrm{bp}$; Lanes: 1-2 containing positive control; Lanes: 3-20 containing raw milk samples for detection of $S$. enterica and L. monocytogenes; Lanes 8-12 show positive result for the sth gene of $S$. enterica; Lanes $7,13,15$ show positive result for the $p l c A$ gene of $L$. monocytogenes; Lane- NC containing no amplified band of K. pneumoniae (Negative control)

\section{Specificity of the target strains using PCR method}

The specificity of PCR depends on the primers designed against variable sequences of bacterial genes of both the pathogens and should not cross-react with the DNA obtained from other heterologous bacteria. To confirm the specificity of the primers, a mixture of all primer sets was used in PCR containing genomic DNA from different standard bacterial strains (Figure 4). The results showed that the primers did not cross-react with another heterologous bacterial DNA. The primers detecting specific gene from one pathogen did not interact with primers detecting specific gene from another pathogen, also with other standard pathogens under the selected PCR conditions.

\section{Sensitivity of the artificially spiked samples using mPCR method}

The sensitivity of the mPCR was estimated by the minimal concentrations required to generate all of the expected bands. The sensitivity of the MPCR was determined for overnight-enumerated samples of S. enterica and L. monocytogenes. The milk samples were serially diluted and cell lysates were used as templates for mPCR amplification. Each sample containing pathogen was diluted to $10^{9}, 10^{8}, 10^{7}$, $10^{6}, 10^{5}, 10^{4}, 10^{3}, 10^{2}$, and $10^{1}$ bacterial cell $/ \mathrm{mL}$ and the PCR result showed that both the foodborne pathogens were detected up to $10^{5}$ dilution of the bacterial cell. (Table 3) The highest minimal concentration of template DNA required for the 
reaction was observed approximately $6.6 \times 10^{\circ} \mathrm{CFU} / \mathrm{mL}$ with $S$. enterica and $4.5 \mathrm{x}$ $10^{\circ} \mathrm{CFU} / \mathrm{mL}$ with $L$. monocytogenes.

Table 2. Detection of Salmonella enterica and Listeria monocytogenes in raw milk samples by conventional methods and PCR method using stn gene and plcA gene as a specific genetic marker (A) for Salmonella enterica (B) for Listeria monocytogenes

\begin{tabular}{|c|c|c|c|c|c|c|}
\hline \multirow{2}{*}{ Sample } & \multirow{2}{*}{$\begin{array}{c}\text { Microscopic examination } \\
\text { (Gram -ve) }\end{array}$} & \multicolumn{4}{|c|}{ Biochemical tests } & \multirow{2}{*}{ PCR } \\
\hline & & $\mathbf{C}$ & $\mathbf{O}$ & MR & VP & \\
\hline $\begin{array}{c}\text { Control } 1 \\
\text { Salmonella enterica }\end{array}$ & ( & + & - & + & - & + \\
\hline $\begin{array}{c}\text { Control } 2 \\
\text { Salmonella enterica }\end{array}$ & - & + & - & + & - & + \\
\hline 3 & + & - & + & + & - & - \\
\hline 4 & + & - & - & - & - & - \\
\hline 5 & + & - & + & - & - & - \\
\hline 6 & - & - & + & - & - & - \\
\hline 7 & + & - & - & + & - & - \\
\hline 8 & + & - & - & - & - & + \\
\hline 9 & + & - & + & + & + & - \\
\hline 10 & + & - & + & - & - & - \\
\hline 11 & - & - & + & - & - & - \\
\hline 12 & + & - & - & + & + & + \\
\hline 13 & + & + & + & - & + & - \\
\hline 14 & + & + & - & + & - & - \\
\hline 15 & + & - & - & + & - & - \\
\hline 16 & + & - & + & - & - & - \\
\hline 17 & - & - & + & - & - & - \\
\hline 18 & + & - & + & - & + & - \\
\hline 19 & + & - & - & - & - & - \\
\hline 20 & + & + & - & - & + & - \\
\hline \multicolumn{7}{|l|}{ (B) } \\
\hline \multirow{2}{*}{ Sample } & Microscopic examination & \multicolumn{4}{|c|}{ Biochemical tests } & \\
\hline & (Gram-ve) & $\mathbf{C}$ & $\mathbf{O}$ & MR & VP & PCR \\
\hline $\begin{array}{c}\text { Control } 1 \\
\text { Listeria monocytogenes }\end{array}$ & + & + & - & + & + & + \\
\hline Control 2 & + & + & - & + & + & + \\
\hline Listeria monocytogenes & + & + & - & + & + & ${ }^{+}+$ \\
\hline 3 & - & - & - & + & - & - \\
\hline 4 & - & - & - & - & + & - \\
\hline 5 & - & - & - & - & - & - \\
\hline 6 & + & + & - & + & - & - \\
\hline 7 & - & - & - & - & + & + \\
\hline 8 & - & - & - & - & + & - \\
\hline 9 & - & - & - & + & - & - \\
\hline 10 & - & - & - & - & + & - \\
\hline 11 & - & - & - & - & - & - \\
\hline 12 & - & - & - & + & - & - \\
\hline 13 & - & - & - & - & - & + \\
\hline 14 & - & - & - & + & - & - \\
\hline 15 & - & - & - & + & + & + \\
\hline 16 & - & - & - & - & - & - \\
\hline 17 & + & + & - & - & + & - \\
\hline 18 & - & - & - & + & - & - \\
\hline 19 & - & - & - & + & + & - \\
\hline 20 & + & - & - & - & - & - \\
\hline
\end{tabular}

Where $\mathrm{C}=$ Catalase test, $\mathrm{O}=$ Oxidase test, $\mathrm{MR}=$ Methyl Red test $\mathrm{VP}=$ Voges Proskauer test 


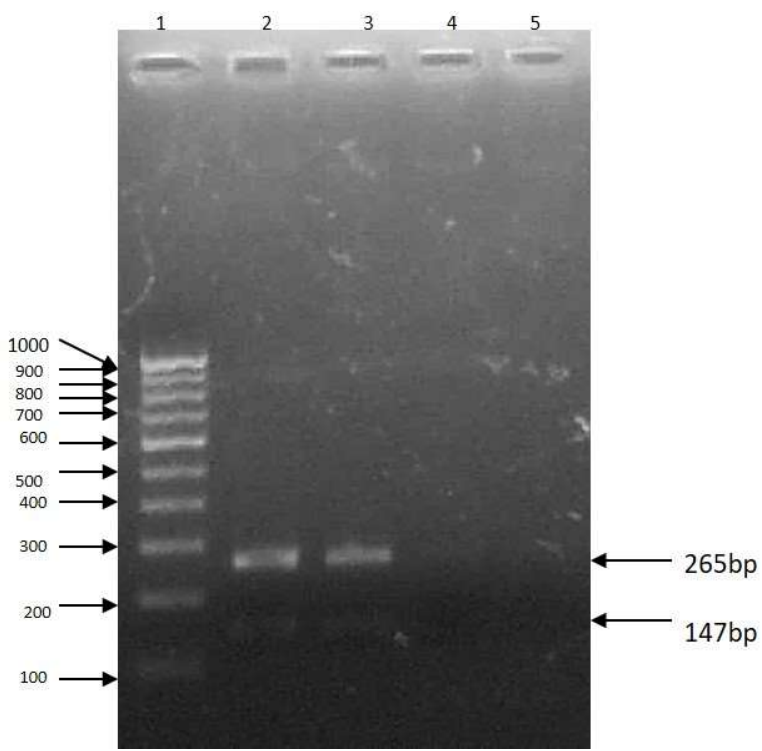

Figure 4. Agarose gel electrophoresis (1.5\%) of PCR product of selected pathogens $(S$. enterica and L. monocytogenes) and standard pathogens (K. pneumoniae and E. aerogenes) showing mPCR results to check the specificity. Lane1: DNA marker 100bp; Lane 2, 3 PCR product containing DNA samples of both $S$. enterica and L. monocytogenes and Lane

4- PCR product containing DNA samples of $K$. pneumoniae and Lane 5- PCR product containing DNA samples of $E$. aerogenes

Table 3. Sensitivity of developed PCR product for the detection of selected pathogens by using different dilutions of artificially spiked raw milk sample

\begin{tabular}{cccc}
\hline $\begin{array}{c}\text { Salmonella } \\
\text { enterica } \\
\text { (cells/mL) }\end{array}$ & $\begin{array}{c}\text { PCR } \\
\text { analysis }\end{array}$ & $\begin{array}{c}\text { Listeria } \\
\text { monocytogenes } \\
\text { (cells/mL) }\end{array}$ & $\begin{array}{c}\text { PCR } \\
\text { analysis }\end{array}$ \\
\hline $10^{1}$ & + & $10^{1}$ & + \\
$10^{2}$ & + & $10^{2}$ & + \\
$10^{3}$ & + & $10^{3}$ & + \\
$10^{4}$ & + & $10^{4}$ & + \\
$10^{5}$ & + & $10^{5}$ & + \\
$10^{6}$ & - & $10^{6}$ & - \\
$10^{7}$ & - & $10^{7}$ & - \\
$10^{8}$ & - & $10^{8}$ & - \\
$10^{9}$ & - & $10^{9}$ & - \\
\hline
\end{tabular}

S. enterica and L. monocytogenes are the primary foodborne pathogens responsible for foodborne disease that causes hospitalizations and deaths (Scallan et al., 2011; Zhao et al., 2014). The conventional methods used for the detection of these 
organisms are time consuming and laborious, so there is need to develop rapid detection method for the foodborne pathogens analyses in food samples (DíazLópez et al., 2011). PCR is the common and mostly used detection method for the pathogens' detection due to the high sensitivity and specificity. For Salmonella spp. detection, genes invA and omp $C$, and for L. monocytogenes hly $A$ gene are more prevalent and commonly used (de Freitas et al., 2010; Soni et al., 2013; Kaur et al., 2007). In the present study, stn and plcA genes are targeted which are widely spread in both the pathogens. mPCR based specific genetic marker was developed for the simultaneous detection and specificity of the both microorganisms. The sensitivity of both pathogens was confirmed in milk samples.

The developed method is highly specific, sensitive and can detect the pathogens in just $80 \mathrm{~min}$. It can detect $6.6 \times 10^{\circ} \mathrm{CFU} / \mathrm{mL}$ of $S$. enterica and $4.5 \times 10^{\circ} \mathrm{CFU} / \mathrm{mL}$ of L. monocytogenes with artificially contaminated milk by using mPCR. The sensitivity of developed genetic marker is highest in comparison to other reported methods (Nguyen et al., 2016).

\section{Conclusions}

mPCR based genetic marker was developed for the simultaneous detection of stn gene and plcA gene for both the pathogens. The developed mPCR based genetic marker is highly $90 \%$ specific, sensitive and can detect the pathogens in $80 \mathrm{~min}$. The detection limit of the assay for the $S$. enterica was $6.6 \times 10^{\circ} \mathrm{CFU} / \mathrm{mL}$ and for $L$. monocytogenes was $4.5 \times 10^{\circ} \mathrm{CFU} / \mathrm{mL}$.

\section{Acknowledgments}

The authors are thankful to Shoolini University, Solan, Himachal Pradesh for providing the facility to carry out the present research work.

\section{References}

Abubakar, I., Irvine, L., Aldus, C.F. 2007. A systematic review of the clinical, public health and cost-effectiveness of rapid diagnostic tests for the detection and identification of bacterial intestinal pathogens in faeces and food. Health Technology Assessment, 11(36), 1-216.

Arora, P., Sindhu, A., Dilbaghi, N., Chaudhury, A. 2011. Biosensors as innovative tools for the detection of food borne pathogens. Biosensors and Bioelectronics, 28(1), 1-12.

Bhunia A.K. 2018. Listeria monocytogenes. In: Foodborne Microbial Pathogens.Food Science Text Series. Springer, New York, NY

Boyle, C., Bishop, L., Grassl, A., Finlay, B. 2007. Salmonella: from pathogenesis to therapeutics. Journal of Bacteriology, 189(5), 1489-1495.

Chopra, K., Huang, H., Xu, J., Burden, K., Niesel, W., Rosenbaum, W., Popov, L., Peterson, W. 1999. Role of Salmonella enterotoxin in overall virulence of the organism. Microbial Pathogenesis, 27(3), 155-171.

de Freitas, G., Santana, P., Da, C, Goncalves, S., Barros E.A., Torres, A., Murata, S., Perecmanis, S. 2010. PCR multiplex for detection of Salmonella Enteritidis, Typhi and 
Typhimurium and occurrence in poultry meat. International Journal of Food Microbiology, 139 (1-2), 15-22.

Díaz-López, A., Cantú-Ramírez, C., Garza-González, E., Ruiz-Tolentino, L., Tellez-Luis, J., Rivera, G., Bocanegra-Garcia, V. 2011. Prevalence of foodborne pathogens in grilled chicken from street vendors and retail outlets in Reynosa, Tamaulipas, Mexico. Journal of food protection, 74(8), 1320-1323.

Dinjus, U., Hänel, I., Müller, W., Bauerfeind, R., Helmuth, R. 1997. Detection of the induction of Salmonella enterotoxin gene expression by contact with epithelial cells with RT-PCR. FEMS Microbiolgy Letters, 146(2), 175-179.

Guard, J., Sanchez-Ingunza, R., Morales, C., Stewart, T., Liljebjelke, K., Van, J., Ingram, K., Jones, D., Jackson, C., Fedorka-Cray, P., Frye, J. 2012. Comparison of dkgB-linked intergenic sequence ribotyping to DNA microarray hybridization for assigning serotype to Salmonella enterica. FEMS Microbiology Letters, 337(1), 61-72.

He, X., Xu, X., Li, K., Liu, B., Yue, T. 2016. Identification of Salmonella enterica Typhimurium and variants using a novel multiplex PCR assay. Food Control, 65, 152159.

IN, C.D.C. 2014. Estimates of foodborne illness in the United States.

Jarvik, T., Smillie, C., Groisman, A., Ochman, H., 2010. Short-term signatures ofevolutionary change in the Salmonella enterica serovar Typhimurium 14028 genome. Journal of Bacteriology, 192(2), 560-567.

Kaur, S., Malik, S., Vaidya, M., Barbuddhe, B. 2007. Listeria monocytogenes in spontaneous abortions in humans and its detection by multiplex PCR. Journal of Applied Microbiology, 103(5), 1889-1896.

Kaushal, A., Kumar, D., Khare, S., Kumar, A. 2012. speB gene as a specific genetic marker for early detection of rheumatic heart disease in human. Cellular and Molecular Biology, 58(1), 50-54.

Kim, J., Park, H., Lee, H., Nahm, H., Chung, H., Seo, H., Kim, Y. 2006. Identification of Salmonella enterica serovar Typhimurium using specific PCR primers obtained by comparative genomics in Salmonella serovars. Journal of Food Protection, 69(7), 16531661 .

Law, J.F., Ab Mutalib S., Chan, G., Lee, H. 2015. Rapid methods for the detection of foodborne bacterial pathogens: principles, applications, advantages and limitations. Frontiers in Microbiology, 5, 770.

Lee, K., Iwata, T., Shimizu, M., Taniguchi, T., Nakadai, A., Hirota, Y., Hayashidani, H. 2009. A novel multiplex PCR assay for Salmonella subspecies identification. Journal of Applied Microbiology, 107(3), 805-811.

Li, Y. 2016. Establishment and application of a visual DNA microarray for the detection of food-borne pathogens. Analytical Sciences, 32(2), 215-218.

Liu, B., Zhou, X., Zhang, L., Liu, W., Dan, X., Shi, C., Shi, X. 2012. Development of a novel multiplex PCR assay for the identification of Salmonella enterica Typhimurium and Enteritidis. Food Control, 27(1), 87-93.

Makino, I., Kurazono, H., Chongsanguam, M., Hayashi, H., Cheun, I., Suzuki, S., Shirahata, T. 1999. Establishment of the PCR system specific to Salmonella spp. and its application for the inspection food and fecal samples. Journal of Veterinary Medical Science,61(11), 1245-1247. 
McLauchlin, J., Mitchell, R.T., Smerdon, W.J., Jewell, K. 2004. Listeria monocytogenes and listeriosis: A review of hazard characterisation for use in microbiological risk assessment of foods. International Journal of Food Microbiology, 92, 15-33.

Moore, M. and Feist, D. 2007. Real-time PCR method for Salmonella spp. targeting the stn gene. Journal of Applied Microbiology, 102(2), 516-530.

National centre of disease control (NCDC) 2017. [Accessed 2017 December] https://www.hindustantimes.com/health/after-diarrhoeal-diseases-food-poisoningcommonest reported-outbreak-in-india/story-jbmVyqJ8jAe03vSVbt6xwK.html

Nguyen, T., Van V., Vo, K. 2016. Multiplex PCR for simultaneous identification of E. coli O157: H7, Salmonella spp. and L. monocytogenes in food. 3 Biotech, 6(2), 205.

Oliver, P., Jayarao, M., Almeida, A. 2005. Foodborne pathogens in milk and the dairy farm environment food safety and public health implications. Foodborne Pathogens and Disease, 2(2), 115-129.

Park, H., Kim, J., Cho, H., Kim, H., Oh, H., Kim, H., Lee, K., Ricke, C., Kim, Y. 2009. Identification of Salmonella enterica subspecies I, Salmonella enterica serovars Typhimurium, Enteritidis and Typhi using multiplex PCR. FEMS Microbiology Letters, 301(1), 137-146.

Rao S., Naveen K., Polasa, K. 2012. Foodborne diseases in India-a review. British Food Journal, 114(5), 661-680.

Scallan, E., Hoekstra, M., Angulo, J., Tauxe, V., Widdowson, A., Roy, L., Jones, L., Griffin, M. 2011. Foodborne illness acquired in the United States major pathogens. Emerging Infectious Diseases, 17(1), 7-15.

Soni, K., Singh, K., Singh, V., Dubey, K. 2013. Characterization of Listeria monocytogenes isolated from Ganges water, human clinical and milk samples at Varanasi India. Infection Genetics Evolution, 14, 83-91.

USFDA/CFSAN, 2003. Detection and Enumeration of L. monocytogenes and Salmonella in foods. Bacteriological Analytical Manual (BAM); http://www.cfsan.fda.gov [Chapter $10]$.

Vazquez, B.J., Kuhn, M., Berche, P., Chakraborty, T., Dominguez, BG. 2001. Listeria pathogenesis and molecular virulence determinants. Clinical Microbiology Reviews, 14 584-640.

Zhao, X., Lin, W., Wang, J., O.H, H. 2014. Advances in rapid detection methods for foodborne pathogens. Journal of Microbiology and Biotechnology, 24(3), 297-312. 